\title{
Олександр Бардах
}

Дніпропетровський регіональний інститут державного управління

Національної академії державного управління при Президентові України

\section{Цифрова трансформація взаємодії влади та бізнесу: орієнтація на результат}

Мета доповіді - привернути увагу до можливості і необхідності використання цифрових технологій для забезпечення орієнтації публічного управління на результат при взаємодії з бізнесом. Надано визначення цифрової трансформації. Розглянуто зв'язок між цифровою трансформацією і параметрами якості публічного управління. Аналізується досвід цифровізації у передових країнах світу. Надані пропозиції до формування нового стратегічного документу з питань цифрового розвитку України.

Ключові слова: великі дані, штучний інтелект, інтернет речей, розподілені реєстри, орієнтація на результат, ијифровізаиія публічного управління

\section{Digital transformation of interaction between government and business: result orientation}

\section{Oleksandr Bardakh, Dnipropetrovsk Regional Institute for Public Administration National Academy for Public Administration under the President of Ukraine}

The purpose of the report is to draw attention to the possibility and necessity of using digital technologies to ensure the orientation of public administration on the result of interaction with business. The definition of digital transformation is given. The connection between digital transformation and quality parameters of public administration is considered. The experience of digitalization in the advanced countries of the world is analyzed. proposals for the formation of a new strategic document on digital development of Ukraine.

Keywords: big data, artificial intelligence, Internet of Things, distributed registers, result orientation, digitization of public administration

I снує певний ризик, що цифровізация економіки та суспільства, яка зараз активно декларується на різних політичних рівнях, стане самоціллю і буде обмежуватися лише деякими змінами в процесах взаємодії органів влади з бізнесом, як найбільш зацікавленою рушійною силою цифрового прогресу. Такий розвиток подій загальмує становлення в Україні цифрової економіки i, отже, посилить відставання нашої країни від країн-лідерів. На наш погляд, важливо уникнути цього ризику. Треба домогтися, щоб пов'язані з цифровізацією зміни призводили до такого зростання якості діяльності влади, яке було б відчутно і прийнято громадянами та бізнесом.

Цифровою трансформацією може визнаватися тільки зміна, на основі впровадження цифрових технологій, змісту всієї системи управління у країні, i, у першу чергу, до підвищення якості публічного управління: зниження необгрунтованого публічного втручання, підвищення результативності та ефективності діяльності органів держави і місцевого самоврядування. Природно, це потре-

бує змін як окремих процедур управління, так і загалом функцій публічного управління.

За даними міжнародної Організації Економічного Співробітництва та Розвитку існує прямий зв'язок між цифрової трансформацією і параметрами якості публічного управління: індексом результативності уряду, індексом контролю корупції і індексом Doing Business. Виявлено також взаємозв'язок між розвитком електронних послуг і рівнем ефективності державних і місцевих видатків (OECD, 2018). Загалом у світі цифровізація публічного управління однозначно асоціюється з підвищенням його якості.

У зарубіжній практиці цифрова трансформація публічного управлінні не зводиться тільки до змін при наданні адміністративних послуг. Значними є можливості сучасних цифрових технологій для трансформації вироблення державної політики і нормотворчості, адміністрування доходів, управління державним майном, контрольно-наглядової діяльності (Квітка, 2017). При цьому цифрові технології використовуються для цілей планування, моніторингу та оцін- 
ки результатів діяльності органів влади. Усе це найважливіші питання для ведення успішного бізнесу в правовому полі держави.

Ефект від цифровізації можна оцінювати за впливом цифрових технологій на ці результати. Іншими словами, цифровізація може стати базою подальшого освоєння органами публічної влади принципу управління за результатами, оскільки дозволяє подолати його раніше виявлені обмеження. Як показує досвід країн, просунутих у справі цифровізації:

- використання «великих даних» дозволяе отримувати інформацію про результати, що досягаються в режимі, близькому до реального часу;

- штучний інтелект не обмежений у сприйнятті декількома показниками і допомагає обробляти тисячі параметрів і вибирати оптимальні рішення;

- інтернет речей дозволяє збирати дані і коригувати дії автоматично, без необхідності звернення до чиновника;

- технології розподіленого реєстру виключають можливість спотворення даних про результати, що досягаються.

Сучасна політика цифровізації в Україні, насправді, мало враховує можливості використання цифрових технологій для підвищення результативності роботи органів влади орієнтованої на результат. Прийнята в 2018 р. Концепція цифрового розвитку України не дає відповіді на питання стратегічного планування цифровізації, обмежуючись загальними деклараціями і побажаннями. Відсутня «дорожня карта» спільних дій з бізнесом, як найбільш зацікавленим стейкхолдером цифрових трансформацій. Зрештою термін дії цієї Концепції закінчується в цьому році, а проекту нового стратегічного документа у цій сфері досі немає (Про схвалення Концепції, 2018).
Між тим, досвід впровадження реформ останніми роками (медичної, освітньої) доводить, що без широкого експертного обговорення такі зміни можуть викликати негативний ефект і засудження громадянами і бізнесом.

На наш погляд, у новій стратегії цифрової трансформації необхідно передбачити блок завдань і заходів 3 цифровізації публічного управління $з$ орієнтацією на результат їх діяльності, зокрема:

- перехід від відповідальності відомств за підготовку та подання звітів про досягнуті результати до їх відповідальності за розміщення даних про результати, що досягаються, що формуються переважно автоматично на єдиній платформі, і ухвалення рішень на основі цих даних;

- розширення використання «великих даних» для цілей вироблення економічної політики, формування офіційної статистики, адміністрування доходів, аудиту результативності бюджетних витрат і реалізації інших державних функцій, з урахуванням пропозицій бізнес-асоціацій;

- розширення методів оцінки результативності державних органів: перехід від бінарної оцінки «виконано - не виконано» до використання предиктивної аналітики, вибіркових контрольованих перевірок, інших аналітичних методів, заснованих на технологіях штучного інтелекту;

- використання цифровізації як інструменту оптимізації бюджетних витрат: впровадження практики розрахунку транзакційних витрат i оцінки їх скорочення за рахунок цифровізації.

Реалізація цих пропозицій допоможе зняти технологічні, кадрові, організаційні і правові обмеження цифровізації взаємодії влади з бізнесом і переходу органів публічного управлінняна діяльність з орієнтацією на результат.

\section{БІБЛІОГРАФІЧНІ ПОСИЛАННЯ}

Квітка, С. А. (2017). Державне управління формуванням партнерських відносин між владо. та бізнесом в умовах сочіальних перетворень. Дніпро: «Грані».

Про схвалення Концепції розвитку цифрової економіки та суспільства України на 2018-2020 роки та затвердження плану заходів щодо іiі реалізації. № 67-p. (2018). Відновлено з https://zakon.rada.gov.ua/laws/show/67-2018-p\#Text

OECD Embracing Innovation in Government. Global Trends 2018. (2018). OECD Publishing, Paris. Retrieved from http:// www.oecd.org/gov/innovative-government / embracing-innovation-in-government-2018. Pdf. 